\title{
Assessment of Heart Rate Variability in Children with Cancer after Elevated Cumulative Anthracycline Dose: A Prospective Study
}

\author{
Kanserli Çocuklarda Artan Kümülatif Antrasiklin Dozunda Kalp Hızı \\ Değişkenliğinin Değerlendirilmesi: Prospektif Bir Çalışma
}

\author{
Sultan AYDIN KOKER ${ }^{1}$, Bengü DEMIRAG ${ }^{1}$, Timur MESE², Murat Muhtar YILMAZER², Yesim OYMAK', \\ Rahmi OZDEMIR ${ }^{3}$, Tuba Hilkay KARAPINAR ${ }^{1}$, Dilek INCE ${ }^{4}$, Raziye Canan VERGIN ${ }^{1}$
}

\author{
${ }^{1}$ Dr. Behçet Uz Children's Hospital, Department of Pediatric Hematology and Oncology, Izmir, Turkey \\ ${ }^{2}$ Dr. Behçet Uz Children's Hospital, Department of Pediatric Cardiology, Izmir, Turkey \\ ${ }^{3}$ Dumlupinar University Faculty of Medicine, Kutahya Health Sciences University Faculty of Medicine Department of Pediatric \\ Cardiology, Kütahya, Turkey \\ ${ }^{4}$ Dokuz Eylül University School of Medicine, Department of Pediatric Oncology, Izmir, Turkey
}

\begin{abstract}
Objective: Anthracyclines which are the main drug of chemotherapy protocols had cardiotoxicity as the most frequent and well-known side effect. We aimed to evaluate prospectively the heart rate variability with 24-hour Holter electrocardiography (ECG) in children with cancer who treated with anthracycline drugs.

Material and Methods: The 24-hour Holter ECG monitoring was performed at the baseline, at time of $120 \mathrm{mg} / \mathrm{m}^{2}$ and $\geq 240 \mathrm{mg} / \mathrm{m}^{2}$ of cumulative anthracycline dose in patients with cancer who treated with anthracycline. The time-domain and frequency-domain measurements of heart rate variability (HRV) were obtained. The patients were classified into three groups as Group1:at baseline( $n=54)$, Group 2: $\geq 120 \mathrm{mg} / \mathrm{m}^{2}(\mathrm{n}=54)$, Group 3: $\geq 240 \mathrm{mg} / \mathrm{m}^{2}(\mathrm{n}=54)$.

Results: The median age was 48 months (range 9-192 months). All types of cancer were 38 patients (70.4\%) of acute leukemia, two patients (3.8\%) of T lymphoblastic lymphoma, and 14patients (25.8\%) of other childhood cancer who treated with anthracycline. However, all heart rate variability parameters were decreased after each increased cumulative anthracycline dose, especially time-domain parameters such as nSDNN index, rMSSD, pNN50, frequency parameters such as LF, HF, and Total power were significantly altered among Group1 and Group 3. LF/HF ratio was also statistically significantly increased in Group 3. According the heart rate parameters, the mean average heart rate, mean minimum heart rate and mean RR were statistically significantly prolonged from Group1 to Group 3.

Conclusion: Heart rate variability parameters are a noninvasive technique to demonstrate cardiac autonomic neural dysfunction and early myocardial injury. The 24-hour Holter ECG may be used for detecting early cardiac dysautonomia effect during anthracycline treatment with each elevated $120 \mathrm{mg} / \mathrm{m}^{2}$ anthracycline of cumulative dose.
\end{abstract}

Key Words: Cardiotoxicity, Cumulative anthracycline, Heart rate variability

Öz

Amaç: Kemoterapi protokollerinin temel ilacı olan antrasiklinler en sık kardiyotoksisite yan etkisine sahiptir. Antrasiklin ile tedavi edilen kanserli çocuklarda kalp hızı değişkenliğini 24 saatlik Holter elektrokardiyografi (EKG) ile prospektif olarak değerlendirmeyi amaçladık.

(i) AYDIN S KOKER DEMIRAG B MESE T YILMAZER MM OYMAKY OZDEMIR R KARAPINAR TH INCE D VERGIN RC
Conflict of Interest / Çıkar Çatışması: On behalf of all authors, the corresponding author states that there is no conflict of interest.

: 0000-0002-8801-7776 0000-0001-5213-7162 : :0000-0002-4433-3929 :0000-0003-0819-5829 $0000-0002-2775-166 x$ $0000-0002-4714-332 x$ $0000-0002-7914-7886$ 0000-0002-8594-9762

Ethics Committee Approval / Etik Kurul Onayl: The study was approved by the Dokuz Eylül University Faculty of Medicine Clinical Research Ethics Committee with the decision number 2014 / 24-17 dated 30.10.2014

Contribution of the Authors / Yazarların katkısI: AYDIN KOKER S: Constructing the hypothesis or idea of research and/or article, Taking responsibility in the writing of the whole or important parts of the study. DEMIRAG B: Taking responsibility in the writing of the whole or important parts of the study. MESE T: Taking responsibility in necessary literature review for the study. YILMAZER MM: Providing personnel, environment, financial support tools that are vital for the study. OYMAK Y: Taking responsibility in logical interpretation and conclusion of the results. OZDEMIR R: Taking responsibility in patient follow-up, collection of relevant biological materials, data management and reporting, execution of the experiments. KARAPINAR responsibility in patient follow-up, collection of relevant biological materials, data management and reporting, execution of the experiments. KARAPINAR RC: Organizing, supervising the course of progress and taking the responsibility of the research/study.

How to cite / Atıf yazım șekli : Aydın Koker S, Demirbag B, Mese T, Y Ilmazer MM, Oymak Y, Ozdemir R, et al. Assessment of Heart Rate Variability in Children with Cancer after Elevated Cumulative Anthracycline Dose: A Prospective Study. Turkish J Pediatr Dis 2021;15:216-221.
Correspondence Address / Yazıșma Adresi:

\section{Sultan AYDIN KOKER}

Dr. Behçet Uz Children's Hospital,

Department of Pediatric Hematology and Oncology, İzmir, Turkey

E-posta: drsultanaydin@hotmail.com
Received / Geliş tarihi : : 15.11.2020 Accepted / Kabul tarihi : 15.02.2021 Online published 15.04 .2021

Elektronik yayın tarihi

DOI: $10.12956 /$ tchd.826263 
Gereç ve Yöntemler: Antrasiklin ile tedavi edilen kanserli hastalarda hiç tedavi almadan, 120mg/m² ve $\geq 240 \mathrm{mg} / \mathrm{m}^{2}$ kümülatif antrasiklin dozunda 24 saatlik Holter EKG monitörizasyonu yapıldı. Kalp atış hızı değișkenliğinin (HRV) zaman alanı ve frekans alanı ölçümleri elde edildi. Hastalar üç gruba ayrıldı: hiç tedavi almadan Grup 1 ( $n=54)$, Grup $2: \geq 120$ mg/m² $(n=54)$, Grup 3: $\geq 240$ mg/m² $(n=54)$ seklinde ayrild.

Bulgular: Ortanca yaş 48 aydı (aralık 9-192 ay). 38 (\% 70.4) hasta akut lösemi, iki hasta T lenfoblastik lenfoma (\% 3.8) ve 14 hasta (\% 25.8) diğer çocukluk çağı kanserleridir. Bununla birlikte, tüm kalp hızı değişkenleri, nSDNN indeksi, rMSSD, pNN50 gibi zaman parametreleri ve LF, HF ve Toplam güç gibi frekans parametreleri gibi her artan kümülatif antrasiklin dozu ile azalma görüldüğü belirlendi. LF/HF oranı da Grup 3’te istatistiksel olarak anlamlı şekilde artış gösterdiği saptandı. Kalp hızı parametrelerine göre, ortalama kalp hızı, ortalama minimum kalp hızı ve ortalama RR, kümülatif doz artıkça istatistiksel olarak anlamlı şekilde uzadığı belirlendi.

Sonuç: Kalp hızı değişkenleri, kardiyak otonomik nöral disfonksiyonu ve erken miyokardiyal hasarın gösterilmesi için invazif olmayan bir tekniktir. 24 saatlik Holter EKG'si, her artan 120 mg/m² antrasiklin kümilatif dozu ile antrasiklin tedavisi sırasında erken kardiyak dysautonomia etkisini saptamak için kullanılabilir.

Anahtar Sözcükler: Kardiyotoksisite, Kümülatif antrasiklin, Kalp hızı değişkenliği

\section{INTRODUCTION}

Anthracycline-induced cardiotoxicity changes from subclinical ventricular dysfunction to severe cardiomyopathy and heart failure. These cardiotoxic events are generally categorized by their time of onset as acute (occurring during or immediately after treatment), early (occurring within1 year of exposure), or late (occurring 1 or more years after initial exposure) (1-4).

It is well known that anthracycline-induced cardiotoxicity is dose-dependent (5). The cumulative percentage of patients who experienced an on-study cardiac event was $7 \%$ at a cumulative doxorubicin dose of $150 \mathrm{mg} / \mathrm{m}^{2}$, increasing to $9 \%$, $18 \%, 38 \%$, and $65 \%$ of patients at cumulative doses of 250 $\mathrm{mg} / \mathrm{m}^{2}, 350 \mathrm{mg} / \mathrm{m}^{2}, 450 \mathrm{mg} / \mathrm{m}^{2}$, and $550 \mathrm{mg} / \mathrm{m}^{2}$, respectively.

Although these are not an exact standard method for assessing cardiotoxicity, 12 derivations electrocardiography (ECG), 24hour Holter ECG or echocardiography, can be used. The 24hour Holter ECG monitoring includes a continuous recording of all electrocardiographic data for a period of 24 or 48 hours. A typical Holter monitor report includes total heartbeats, average heart rate, maximum and minimum heart rates, number of premature beats (supraventricular and ventricular), episodes of tachyarrhythmia and the etiology of the arrhythmias (eg, supraventricular or ventricular), longest $R-R$ interval and any pauses greater than three seconds and etiology of the pauses (eg, sinus pauses versus AV block), and ST-segment change $(6,7)$. The 24-hour Holter ECG also provides more prognostic information apart from the detection of arrhythmias such as heart rate variability (HRV). Therefore, the autonomic nervous system function can be assessed when the various time domains of HRV are measured.

To the best of our knowledge, the studies which assess the anthracycline-induced cardiotoxicity with the 24-hour Holter ECG, are rare. Therefore, we aim to identify important predictors of arrhythmias, subclinical ventricular dysfunction, acute and early cardiotoxic events, and the HRV after increased cumulative anthracycline dose with 24-hour Holter ECG in children with cancer who treated with anthracycline drugs.

\section{MATERIALS and METHODS}

This study was performed between September 2014 and September 2015 at Dr. Behçet Uz Children Hospital, Turkey. Children with cancers who were treated with any anthracycline drugs were included in the study group. All patients were evaluated by the 24-hour Holter ECG monitoring at the baseline, at the time $\geq 120 \mathrm{mg} / \mathrm{m}^{2}$ and $\geq 240 \mathrm{mg} / \mathrm{m}^{2}$ of cumulative anthracycline dose in the 54 patients with cancer who treated with anthracycline, respectively. The patients were classified into three groups according to increasing cumulative anthracycline doses: Group 1: at baseline ( $\mathrm{n}=54)$, Group 2: $\geq 120 \mathrm{mg} / \mathrm{m}^{2}$ $(n=54)$, Group 3: $\geq 240 \mathrm{mg} / \mathrm{m}^{2} \quad(n=54)$. The data of 24-hour Holter ECG monitoring which obtained at the baseline (Group 1) were accepted as the control group. From the archive files, the following data of the patients were collected such as age, gender, history, physical examination, and medical information. Written informed consent was obtained from all parents.

Children with cancers who have not the administration of anthracycline drugs, and patients whose arrhythmia was detected in the evaluation of the 24-hour Holter ECG monitoring at the baseline time were excluded from this study.

The study was approved by the Dokuz Eylül University Faculty of Medicine Clinical Research Ethics Committee with the decision number 2014 / 24-17 dated 30.10.2014.

\section{Holter ECG}

The 24-hour Holter ECG inputs were recorded with threechannel DMS 303A V11a Holter Recording Device (DMS Inc., New York, NY, USA). The recordings included a complete day and night cycle. All recordings were analyzed using DMS Cardioscan program (DMS Cardioscan 11.0 Holter analysis program, DMS Software Inc., ABD. First of all, all the records were cleaned from artifacts then ectopic beats and arrhythmias were determined. In the 24-hour records, the following data were obtained: minimum, maximum, and mean HRs, ventricular or supraventricular ectopic beats, ventricular tachycardia (VT) or supraventricular tachycardia (SVT) episodes, atrioventricular block or sinus pause. Noisy data, artifacts, ectopic, and 
arrhythmia beats, pauses were excluded from the analysis. Holter tapes were re-evaluated by a pediatric cardiologist.

\section{HRV analysis}

The following time-domain indices were calculated; the standard deviation of all normal sinus R-R intervals (SDNN); mean of the standard deviations of all normal sinus R-R intervals for all 5-minute segments of the entire recording (SDNNi); the standard deviation of the averages of R-R intervals in all 5-minute segments of the entire recording (SDANN); root mean square of the successive normal sinus $R-R$ interval difference (rMSSD); and the percentage of successive normal sinus R-R intervals longer than 50 milliseconds (pNN50 \%). The calculated frequency-domain indices were: Variance of all R-R intervals total power (TP); power in the very low-frequency range - very low frequency (VLF, 0.003-0.04 Hz); power in the low-frequency range-low frequency $(\mathrm{LF}, 0.04-0.15 \mathrm{~Hz})$; low-frequency power in normalized units-normalized low frequency; power in the highfrequency range-high frequency $(\mathrm{HF}, 0.15-0.40 \mathrm{~Hz})$; and highfrequency power in normalized units-normalized high frequency and the ratio of low frequency to high frequency (LF/HF).

\section{Statistical analysis}

Statistical analyses were performed using the SPSS package program version 21. Kolmogorov-Smirnov test was used to check the normality assumption. Values are expressed as mean $\pm S D$ or median (interquartile range) as appropriate. Oneway analysis of variance (ANOVA) was used to compare the means of normally distributed parameters among the groups. The homogeneity of variances was assessed by the Levene test. Post hoc tests were performed using Tukey's method when an overall significance was observed. Kruskal-Wallis tests were conducted to compare non-normality distributed variables among groups. Mann-Whitney $U$ test was performed to test the significance of pairwise differences using Bonferroni correction to adjust for multiple comparisons. The relationship between the numerical data is examined by Pearson's correlation analysis. The point biserial correlation model was used to investigate the association between categorical and numeric data. An overall $P$ value of less than 0.05 was considered to show a statistical significance.

\section{RESULT}

\section{Demographic and echocardiographic characteristics}

The data were collected from 54 patients with cancers. There were 33 male $(61.1 \%)$ and 21 female $(38.9 \%)$ patients in the baseline study group. The median age was 48 months (range from 9 to 192 months). Table I showed the type of cancer in our study. All types of cancer were distributed for 38 patients $(70.4$ $\%)$ of acute leukemia, two patients (3.8\%) of T lymphoblastic lymphoma, and 14 patients (25.8\%) of other childhood cancer who treated with anthracycline during chemotherapy protocols.
Table I: Distribution of type of cancer at our study.

\begin{tabular}{lcc}
\hline \multicolumn{1}{c}{ Type of cancer } & $\begin{array}{c}\text { Frequency } \\
\text { (n) }\end{array}$ & $\begin{array}{c}\text { Percent } \\
\text { (\%) }\end{array}$ \\
\hline Acute leukemia (ALL+ AML) & 38 & 70.4 \\
\hline $\begin{array}{l}\text { Lymphoma (HL+ T cell lymphoblastic } \\
\text { lymphoma+ Burkitt lymphoma) }\end{array}$ & 7 & 13.0 \\
\hline Solid tumour & 9 & 16.6 \\
\hline Total & 54 & 100.0 \\
\hline
\end{tabular}

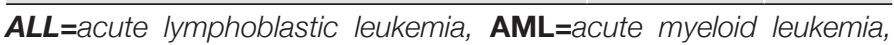
HL= Hodgkin Lymphoma, Burkitt lymphoma, Solid tumour= Neuroblastoma+ Hepatoblastoma+ Ewing sarcoma+ Wilms tumor+ Osteosarcoma)

Two patients died due to sepsis and respiratory failure at the first 20 days of induction therapy. One patient followed up another center.

Fifty-four patients had not malnutrition at the diagnosis time. Any of our patients had not received radiotherapy. Aortic coarctation, tricuspid insufficiency, PFO, ASD, mitral insufficiency, and left shift of intraventricular septum in the mid septal region were detected with echocardiography at 6 of 54 patients. But EF and FS of all patients were detected normale.

Two of 54 patients were detected ventricular extrasystole (VES), nonsustained ventricular tachycardia (VT) at the baseline time of 24-hour Holter ECG monitoring. Antiarrhythmic treatments were started according to these arrhythmia findings.

The mean values of the minimum, maximum, and average heart rates obtained from 24-hour electrocardiography recordings are given in Table II. According to the heart rate parameters, the mean average heart rate, and mean minimum heart rate was statistically prolonged while mean RR was shortened especially from Group 1 to Group $3 \quad(p<0.05)$. Although the mean maximum heart rate was no statistically significant difference between at baseline time, $\geq 120 \mathrm{mg} / \mathrm{m}^{2}$, and $\geq 240 \mathrm{mg} / \mathrm{m}^{2}$ of cumulative anthracycline dose, the mean maximum heart rate was prolonged with elevated cumulative anthracycline dose. Despite no statistically significant difference between Group 1, Group 2, and Group 3, the mean average rate, mean minimum heart rate, and mean maximum heart rate, were become longer, mean RR also was shortened (Table II).

Time and frequency domain indices of HRV parameters in the study are shown in Table III. Time-domain indices SDNN index, rMSSD, pNN50, and frequency domain indices LF, HF, VLF, and total power in Group 3 were significantly lower than in Group $1(<0.05)$. The frequency-domain LH/HF in Group 3 was significantly higher than in Group 1. Despite no statistically significant difference between all groups, all HRV parameters as SDNN, SDANN, SDNN index, rMSSD, pNN50, LF, HF, VLF, total power shortened, while only frequency parameter of $\mathrm{LH} / \mathrm{HF}$ increased during elevated cumulative anthracycline dose. The results of the frequency domain HRV parameters in the study Group 3 showed significant alterations in favor of sympathetic dominance when compared with the group 1 with increased 
Table II: Comparison of heart rate parametres.

\begin{tabular}{|c|c|c|c|c|c|c|}
\hline & Group 1(A) & Group 2 (B) & Group 3 (C) & $p(A-B)$ & $\mathrm{p}(\mathrm{B}-\mathrm{C})$ & $p(A-C)$ \\
\hline Mean Average Heart rate (bpm) & $97.78 \pm 18.1$ & $108.8 \pm 16.96$ & $112.76 \pm 23.55$ & $p=0.039$ & $p=0.155$ & $p=0.001$ \\
\hline Mean Minimum Heart rate (bpm) & $55.66 \pm 9.4$ & $60.0 \pm 10.3$ & $59.2 \pm 7.7$ & $p=0.172$ & $p=0.633$ & $p=0.019$ \\
\hline Mean RR (ms) & $630.30 \pm 108.97$ & $569.1 \pm 82.1$ & $559 \pm 110.5$ & $p=0.043$ & $\mathrm{p}=0.279$ & $p<0.01$ \\
\hline
\end{tabular}

Data are shown as mean \pm standard deviation for normally distributed variables; variables without normal distribution are shown as median (minimum-maximum values)*. Bold values indicate statistical significance.

Table III: Comparison of time- and frequency-domain heart rate variability parameters.

\begin{tabular}{l|c|c|c|c|c|c|}
\hline & Group 1 (A) & Group 2 (B) & Group 3 (C) & $\mathbf{p ~ ( A - B ) ~}$ & $\mathbf{p}(\mathbf{A}-\mathbf{C})$ & $\mathbf{p}(\mathbf{B}-\mathbf{C})$ \\
\hline SDNN & $117.41 \pm 51.62$ & $91.4 \pm 36.1$ & $101.8 \pm 57.76$ & $p=0.187$ & $p=0.086$ & $p=0.120$ \\
\hline SDANN & $105.98 \pm 49.09$ & $77.9 \pm 40.5$ & $91.5 \pm 53.5$ & $p=0.134$ & $p=0.083$ & $p=0.114$ \\
\hline SDNN index & $55.94 \pm 23.99$ & $44.4 \pm 19.7$ & $44.1 \pm 22.04$ & $p=0.391$ & $\mathbf{p}=\mathbf{0 . 0 0 8}$ & $p=0.422$ \\
\hline rMSSD & $43.5 \pm 22.2$ & $29.7 \pm 19.3$ & $32.46 \pm 20.1$ & $p=0.299$ & $\mathbf{p}=\mathbf{0 . 0 1 1}$ & $p=0.476$ \\
\hline pNN50 & $18.07 \pm 14.10$ & $9.9 \pm 12.56$ & $11.34 \pm 12.1$ & $p=0.409$ & $\mathbf{p}=\mathbf{0 . 0 1 0}$ & $p=0.489$ \\
\hline LF & $657.42 \pm 440.12$ & $536.0 \pm 412.0$ & $461.0 \pm 360.0$ & $p=0.631$ & $\mathbf{p}=\mathbf{0 . 0 1 8}$ & $p=0.519$ \\
\hline HF & $474.0 \pm 426.0$ & $282.0 \pm 271.0$ & $247.0 \pm 226.0$ & $p=0.237$ & $\mathbf{p}=\mathbf{0 . 0 0 2}$ & $p=0.318$ \\
\hline VLF & $1996.0 \pm 1570.83$ & $1317.0 \pm 992.0$ & $1473.0 \pm 1342.0$ & $p=0.274$ & $p=0.084$ & $p=0.252$ \\
\hline Total Power & $3169.82 \pm 2352.0$ & $2176.0 \pm 1677.0$ & $2241.0 \pm 1903.0$ & $p=0.323$ & $\mathbf{p}=\mathbf{0 . 0 2 5}$ & $p=0.293$ \\
\hline LH/HF & $2.0 \pm 1.21$ & $2.6 \pm 1.3$ & $2.86 \pm 1.75$ & $p=0.516$ & $\mathbf{p}=\mathbf{0 . 0 2 3}$ & $p=0.960$ \\
\hline
\end{tabular}

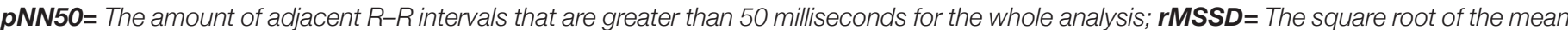
of the sum of squares of differences between adjacent $R-R$ intervals over the length of the analysis; SDANN= The standard deviation of the means of all $R-R$ intervals for all 5-minute segments of the analysis; SDNN= The standard deviation of all R-R intervals over 24 hours; $\mathbf{S D N N}$ index= $S D N N i$, mean of the standard deviations of all normal sinus $R-R$ intervals for all 5-minute segments of the entire recording.

the ratio of low frequency to high frequency, and decreased normalized high frequency and low frequency. All HRV indices in patients between Group 1 and Group 2, were not statistically significant differences. Also, all heart rate variability between Group 2 and Group 3 were not statistically different owing to the low patient numbers.

\section{DISCUSSION}

Anthracyclines, which are commonly used as part of first-line chemotherapy protocols to treat a variety of hematological and solid tumors are known to develop significant cardiac side effects. Cytotoxic anthracyclines and radiotherapy are known to cause persistent and progressive damage to the cardiovascular system. Cardiomyocytes and cardiac progenitor cells have a limited ability to regenerate (8).

The mean values of the minimum, and average heart rates obtained from 24-hour Holter ECG recordings of patients with acute rheumatic fever in the study of Karacan M. et al.(9), were significantly higher than in the healthy control group. In our study, while the heart rate parameters, mean average heart rate, mean minimum heart rate was statistically prolonged, mean RR was shortened especially from Group 1 to Group $3(p<0.05)$.
The mean values of heart rate parameters such as minimum, maximum, and average were similar in patients with isolated carditis and without carditis, with a p-value greater than 0.05 (9). In our study, the mean values of heart rate parameters either between Group 1 and Group 2 or between Group 2 and Group 3, were not significantly different owing to the low patient numbers. In spite of these results, the mean values of the minimum, maximum, and average heart rates were prolonged and the mean RR interval was shortened with increased cumulative anthracycline dose.

The cardiac contractions in healthy subjects are irregular, and the change in the intervals between cardiac contractions is a physiological phenomenon. Heart rate variability can be measured with continuous monitoring of electrocardiography, which provides information about the autonomic balance. The autonomic balance can be evaluated by the analysis of heart rate variability (10). Stachowiak Pet al.(11) detected early heart rate variability changes during chemotherapy, assessed with 24-hour Holter ECG in breast cancer patients. 24-hour Holter ECG and echocardiography examination were performed at baseline, $24 \mathrm{~h}$ after the first cycle of drug administration, and $24 \mathrm{~h}$ after the last cycle of chemotherapy. This study reported that SDNN, SDNN index, and SDANN decreased at the end of chemotherapy. In comparison, heart rate did not change significantly. Time-domain indices of heart rate variability, 
including pNN50 and rMSSD, were worse after drug infusion; however, the changes were not significant difference. In our study; the SDNN index, rMSSD, pNN50, LF, HF, VLF, and Total power in Group 3 were significantly lower than in Group1, in contrast to the results of Stachowiak P at el's study. LH/HF in Group 3 was significantly higher than in Group 1. Despite no statistically significant difference between all groups, all heart rate variability parameters as SDNN, SDANN, SDNN index, rMSSD, pNN50, LF, HF, VLF, and Total power shortened, while $\mathrm{LH} / \mathrm{HF}$ increased with elevated cumulative anthracycline dose. Our study showed decreased parasympathetic and increased sympathetic activity. However, decreased HRV is a predictor of adverse outcomes in myocardial infarction, sudden cardiac death, and congestive heart failure (12). In our study, decreased HRV was detected associated with cardiac dysfunction as similar to given clinical scenarios. SDNN significantly correlated with poor survival (13).

Changes in heart rate variability occurred early after thrombolysis and may be of prognostic value. Heart rate variability measures were improved in patients with better ejection fraction and greater angiographic patency. These data indicate that early heart rate variability assessment after myocardial infarction may be useful in noninvasive risk stratification (14). Low HRV was independently associated with a significant 2-fold increased likelihood for early myocardial ischemia in patients with coronary artery disease (15). Early myocardial injury may be predicted as the result of lower SDNN index, rMSSD, pNN50 parameters in our study.

Arrhythmias can occur after anthracycline administration. Early complications usually occur shortly after drug administration and are generally transient. Late effects may be visible many years after chemotherapy cessation (16). The early complication of life-threatening arrhythmias due to anthracyclines is quite rare. The release of vasoactive factors into the blood soon after doxorubicin infusion, support to sympathetic activation and confirms the arrhythmogenic side effects of anthracyclines (17). In our study, the results of the frequency-domain heart rate variability parameters in the study group 3 showed significant alterations in favor of sympathetic dominance when compared with the group 1 increased the ratio of low frequency to high frequency, and decreased normalized high frequency and low frequency. In our study, the decrease in heart rate variability parameters, suggesting the possibility of worsening/increasing sympathetic activation after drug infusion, was similar to a recent study (18).

\section{Study Limitations}

This study has some limitations. The major limitation is the small patient sample in our study. During follow-up, it was difficult to investigate 24-hour Holter ECG at the appropriate cumulative dose time. Therefore, patients' numbers between groups decreased at follow-up.

\section{CONCLUSION}

We found the correlation between the mean values of HRV parameters at the 24-hour Holter ECG with increased cumulative anthracycline dose at the patients with cancers. The 24-hour Holter ECG may be good guidance for assessing the early cardiac adverse effect during chemotherapy at the patients with cancer because reduced HRV is a predictor of adverse outcomes in myocardial infarction, sudden cardiac death, and congestive heart failure. Further studies with larger samples and longer follow-up periods are needed to support these results.

\section{REFERECES}

1. Lipshultz SE, Alvarez JA, Scully RE. Anthracycline associated cardiotoxicity in survivors of childhood cancer. Heart 2008;94:52533.

2. Van Dalen EC, van der Pal HJ, Kok WE, Caron HN, Kremer LC. Clinical heart failure in a cohort of children treated with anthracyclines: a long-term follow up study. Eur J Cancer 2006;42:3191-8.

3. Sorensen K, Levitt G, Bull C, Chessells J, Sullivan I. Anthracycline dose in childhood acute lymphoblastic leukemia: issues of early survival versus late cardiotoxicity. J Clin Oncol 1997;15:61-8.

4. Lipshultz SE, Colan SD, Gelber RD, Perez Atayde AR, Sallan SE, Sanders SP. Late cardiac effects of doxorubicin therapy for acute lymphoblastic leukemia in childhood. N Engl J Med 1991;324:80815.

5. Swain SM, Whaley FS, Ewer MS. Congestive heart failure in patients treated with doxorubicin: a retrospective analysis of three trials. Cancer 2003;97:2869-79.

6. Zimetbaum PJ, Josephson ME. The evolving role of ambulatory arrhythmia monitoring in general clinical practice. Ann Intern Med 1999;130:848-56.

7. Joshi AK, Kowey PR, Prystowsky EN, Benditt DG, Cannom DS, Pratt CM, et al. First experience with a Mobile Cardiac Outpatient Telemetry (MCOT) system for the diagnosis and management of cardiac arrhythmia. Am J Cardiol 2005;95:878-81.

8. Mulrooney DA, Yeazel MW, Kawashima T, Mertens AC, Mitby P, Stovall $\mathrm{M}$, et al. Cardiac outcomes in a cohort of adult survivors of childhood and adolescent cancer: retrospective analysis of the Childhood Cancer Survivor Study cohort. BMJ 2009;339:b4606.

9. Karacan M, Ceviz N, Olgun $\mathrm{H}$. Heart rate variability in children with acute rheumatic fever. Cardiol Young 2012;22:285-92.

10. Task Force of The European Society of Cardiology and the North American Society of Pacing and Electrophysiology. Heart rate variability-standards of measurement, physiological interpretation, and clinical use. Eur Heart J 1996;17:354-81.

11. Stachowiak P, Milchert-Leszczyńska M, Falco M, Wojtarowicz A, Kaliszczak R, Safranow K, et al. Heart rate variability during and after chemotherapy with anthracycline in patients with breast cancer. Kardiol Pol 2018;76:914-6.

12. Makikallio TH, Huikuri HV, Makikalliob A, Sourander LB, Mitrani RD, Castellanos A, et al. Prediction of sudden cardiac death by fractal analysis of heart rate variability in elderly subjects. J Am Coll Cardiol 2001;37:1395-402. 
13. Kim K, Chae J, Lee S. The role of heart rate variability in advanced non-small-cell lung cancer patients. J Palliat Care 2015;31:103-8.

14. Singh N, Mironov D, Armstrong PW, Ross AM, Langer A. Heart Rate Variability Assessment Early After Acute Myocardial Infarction Pathophysiological and Prognostic Correlates. Circulation 1996;93:1388-95.

15. Goldenberg I, Goldkorn R, Shlomo N, Einhorn M, Levitan J, Kuperstein R, et al. Heart Rate Variability for Risk Assessment of Myocardial Ischemia in Patients Without Known Coronary Artery Disease: The HRV-DETECT (Heart Rate Variability for the Detection of Myocardial Ischemia) Study. J Am Heart Asso 2019;8:e014540.

16. Zamorano J, Lancellotti P, Muñoz D, Aboyans V, Asteggiano R, Galderisi M, et al. Stanowisko ESC dotyczące toksycznego wpływuleczenia onkologicznego na układ sercowo-naczyniowy w 2016 roku, opracowane pod auspicjami Komisji ESC do spraw Wytycznych Postępowania [Position Paper on cancer treatments and cardiovascular toxicity developed under the auspices of the ESC Committee for Practice Guidelines]. Kardiol Pol 2016;74:1193-233.

17. Asensio-López MC, Soler F, Sánchez-Más J, Figal DP, Belda FF, Lax A. Early oxidative damage induced by doxorubicin: Source of production, protection by GKT137831 and effect on $\mathrm{Ca}(2+)$ transporters in HL-1 cardiomyocytes. Arch Biochem Biophys 2016;594:26-36.

18. Poręba M, Poręba R, Gać P, Zubkiewicz LU, Pilecki W, Piotrowicz E, et al. Heart rate variability and heart rate turbulence in patients with hematologic malignancies subjected to high-dose chemotherapy in the course of hematopoietic stem cell transplantation. Ann Noninvasive Electrocardiol 2014;19:157-65 